University of Nebraska - Lincoln

DigitalCommons@University of Nebraska - Lincoln

Faculty Papers and Publications in Animal

Science

Animal Science Department

2006

Determination of Undegradable Intake Protein Digestibility of

Forages Using the Mobile Nylon Bag Technique

H. L. Haugen

University of Nebraska-Lincoln

S. K. Ivan

University of Nebraska-Lincoln

James C. MacDonald

University of Nebraska-Lincoln, jmacdonald2@unl.edu

Terry J. Klopfenstein

University of Nebraska-Lincoln, tklopfenstein1@unl.edu

Follow this and additional works at: https://digitalcommons.unl.edu/animalscifacpub

Part of the Animal Sciences Commons

Haugen, H. L.; Ivan, S. K.; MacDonald, James C.; and Klopfenstein, Terry J., "Determination of Undegradable Intake Protein Digestibility of Forages Using the Mobile Nylon Bag Technique" (2006). Faculty Papers and Publications in Animal Science. 545.

https://digitalcommons.unl.edu/animalscifacpub/545

This Article is brought to you for free and open access by the Animal Science Department at DigitalCommons@University of Nebraska - Lincoln. It has been accepted for inclusion in Faculty Papers and Publications in Animal Science by an authorized administrator of DigitalCommons@University of Nebraska - Lincoln. 


\title{
Determination of undegradable intake protein digestibility of forages using the mobile nylon bag technique ${ }^{1}$
}

\author{
H. L. Haugen, S. K. Ivan, J. C. MacDonald, and T. J. Klopfenstein ${ }^{2}$ \\ Department of Animal Science, University of Nebraska, Lincoln 68583-0908
}

\begin{abstract}
Two experiments were conducted using 2 ruminally and duodenally fistulated steers to determine the digestibility of undegradable intake protein (UIP) of smooth bromegrass (Bromis inermis), birdsfoot trefoil (Lotus coniculatus L.), and heat-treated alfalfa (Medicago sativa) using the mobile nylon bag technique. Undegradable intake protein was determined using neutral detergent insoluble $\mathrm{CP}$ at a single in situ incubation time point based on $75 \%$ of the total mean retention time estimated from IVDMD plus a 10 -h passage lag. In Exp. 1, UIP (\% DM) of smooth bromegrass in June and July were 1.82 and 1.71 , respectively $(P=$ 0.11). Undegradable intake protein (\% DM) of birdsfoot trefoil increased from 1.30 in June to 1.94 in July $(P<$ $0.01)$. Total tract indigestible protein of smooth bromegrass and birdsfoot trefoil increased in July $(P<0.05)$. Digestibility of UIP decreased in July for smooth bromegrass $(P<0.01)$ but tended to increase for birdsfoot
\end{abstract}

trefoil $(P=0.07)$. In Exp. 2, alfalfa from plots fertilized with low (66 kg of N/ha) or high (200 kg of N/ha) amounts of $\mathrm{N}$ were dried to simulate 3 preservation methods: dehydrated $\left(100^{\circ} \mathrm{C}, 10 \mathrm{~h}\right)$, sun-cured $\left(50^{\circ} \mathrm{C}, 15\right.$ $\mathrm{h}$ ), and lyophilized $\left(-50^{\circ} \mathrm{C}, 72 \mathrm{~h}\right)$ alfalfa. Undegradable intake protein (\% DM) was estimated as in Exp. 1 and was $3.13,2.10$, and 1.84 for dehydrated, sun-cured, and lyophilized alfalfa, respectively. Total tract indigestible protein $(\% \mathrm{DM})$ was increased $(P<0.05)$ for dehydrated alfalfa (1.66) compared with sun-cured (1.54) or lyophilized (1.57) alfalfa. As a result of greater UIP flow to the lower tract, digestibility (\%) of UIP was greater $(P$ $<0.01$ ) for dehydrated (46.4) than for sun-cured (25.6) or lyophilized (14.7) alfalfa. Heat-treated alfalfa samples increased net UIP absorption in the lower tract because $1.47,0.56$, and 0.27 percentage units of UIP (\% DM) of dehydrated, sun-cured, and lyophilized alfalfa, respectively, disappeared. Overall, the digestibility of the UIP of these forages was low in the lower tract.

Key words: forage, heat-treated alfalfa, mobile nylon bag, undegradable intake protein digestibility

(C2006 American Society of Animal Science. All rights reserved.

J. Anim. Sci. 2006. 84:886-893

\section{INTRODUCTION}

Protein evaluation systems for beef (NRC, 1996) and dairy (NRC, 2001) cattle recognize that the intestinal digestibilities of proteins may differ by source. Before the 2001 revision of the dairy NRC, a constant digestibility of $80 \%$ was used for the undegradable intake protein (UIP) of all feedstuffs. The protein evaluation system for beef (NRC, 1996) uses a constant digestibility of $80 \%$ because of a lack of available information on UIP digestibility; however, the dairy NRC (2001) now uses variable digestibilities from 50 to $100 \%$.

Erasmus et al. (1994) found that the digestibility of UIP of feedstuffs in the intestine varied significantly. In their experiment, the digestibility of the UIP of al-

\footnotetext{
${ }^{1}$ A contribution of the Univ. of Nebraska Agricultural Research Division, Lincoln 68583. Journal Series No. 14613.

${ }^{2}$ Corresponding author: tklopfenstein1@unl.edu

Received July 24, 2005.

Accepted November 16, 2005.
}

falfa hay $(16.1 \% \mathrm{CP})$ was $66.0 \%$, and the digestibility of UIP of Eragrostis curvula hay (5.7\% CP) was only $37.8 \%$. The digestibility of the UIP of forages may be lower than the digestibility of the UIP of concentrates. Negi et al. (1988) hypothesized that the extensive ruminal degradability of leaves from forage results in residual UIP that is associated with cell walls, which has a low intestinal digestibility. Based on ruminal incubations for 16 h, Frydrynch (1992) reported greater digestibilities for UIP of concentrates $(88.2 \%)$ than of forages $(70.8 \%)$.

The length of incubation of forages in the rumen has a significant influence on the measured intestinal digestibility of undegraded N (Beckers et al., 1996). Many of the values for UIP and the digestibility of forages reported in the literature are based on ruminal incubations of $16 \mathrm{~h}$ or less, which may not reflect the true residence time of forage particles in the rumen (Haugen et al., 2005). Von Keyserlingk et al. (1996) noted that estimates of the digestibility of UIP of forages might be overestimated when rumen incubations are too short. 
Therefore, the objectives of this experiment were to 1) determine UIP content and UIP digestibility of smooth bromegrass and birdsfoot trefoil, and 2) determine the effect of heat treatment on the UIP content and digestibility of UIP of alfalfa.

\section{MATERIALS AND METHODS}

\section{Forage Samples}

In Exp. 1, clip samples of smooth bromegrass (Bromis inermis) and birdsfoot trefoil (Lotus corniculatus L.) were collected from 2 field locations at 2 dates (June and July, 2003) from a smooth bromegrass pasture interseeded with birdsfoot trefoil at the Research and Development Center of the University of Nebraska, near Ithaca, Nebraska. Samples were frozen at $-4^{\circ} \mathrm{C}$, lyophilized $\left(-50^{\circ} \mathrm{C}\right)$ for $72 \mathrm{~h}$, and ground through a 2$\mathrm{mm}$ screen for in situ incubation and a 1-mm screen for laboratory analysis.

In Exp. 2, clip samples of alfalfa (Medicago sativa) from plots fertilized with an average of $200 \mathrm{~kg}$ of N/ha $(17 \mathrm{~kg}$ of $\mathrm{P})$ or $66 \mathrm{~kg}$ of $\mathrm{N} / \mathrm{ha}(18 \mathrm{~kg}$ of $\mathrm{P})$ were used to evaluate the effects of heat treatment and $\mathrm{N}$ fertilization on protein degradability in the rumen and the resulting digestibility of UIP of the small intestine. Samples were hand clipped at $10 \mathrm{~cm}$ above the ground from each of 2 replicate plots. The alfalfa was in the late bud stage of maturity in the third cutting on August 16. The $\mathrm{N}$ fertilization rates were used to produce potential changes in $\mathrm{N}$ metabolism that could induce changes in ruminal degradability of the resulting protein. Alfalfa was frozen at $-4^{\circ} \mathrm{C}$ until drying methods were applied.

Drying methods were simulated in the laboratory and included sun-cured, dehydrated, and lyophilized alfalfa. Sun curing was simulated by drying the sample in a forced-air oven at $50^{\circ} \mathrm{C}$ for $15 \mathrm{~h}$ (Krause and Klopfenstein, 1978). The process of dehydration was simulated by drying the sample in a forced-air oven at $100^{\circ} \mathrm{C}$ for $10 \mathrm{~h}$. Dry samples were ground through a $2-\mathrm{mm}$ screen for in situ analysis and a 1-mm screen for lab analysis.

The IVDMD was conducted on 1-mm ground forage samples in both experiments using the method of Tilley and Terry (1963), which was modified by the addition of $1 \mathrm{~g}$ of urea/L of McDougall's buffer (Weiss, 1994). In vitro DM disappearance was used to estimate the rate of passage $\left(\mathrm{k}_{\mathrm{p}}\right)$ of each of the forages using the following equation: $\mathrm{k}_{\mathrm{p}}=0.07 \times \mathrm{IVDMD}-0.20$, in which IVDMD was expressed as a percentage (Klopfenstein et al., 2001). The $k_{p}$ was then used to determine the mean retention time $\left(\mathrm{MRT}=1 / \mathrm{k}_{\mathrm{p}}\right)$. A 10 -h passage lag was added to the MRT to yield the total mean retention time (TMRT).

\section{In Situ Incubation}

Two ruminally cannulated crossbred heifers (556 kg) were used in Exp. 1 to incubate $5 \times 10$-cm Dacron bags
(Ankom Inc., Fairport, NY) that had a 50- $\mathrm{mm}(\mathrm{SD}=5$ ) pore size. The Dacron bags were placed in mesh bags (50 Dacron bags/mesh bag) with a 100-g weight and placed in the ventral rumen. All surgical procedures were approved by the University of Nebraska Animal Care and Use Committee. A mixed diet of 70\% bromegrass hay and $30 \%$ concentrate was fed twice each day at a cumulative daily rate of $1.5 \%$ of BW (NRC, 2001). Bags containing $1.25 \mathrm{~g}$ of air-dry forage ground through a 2-mm screen were heat-sealed (Vanzant et al., 1998). Duplicate bags were incubated at each time point and replicated over $2 \mathrm{~d}$, for a total of $8 \mathrm{bags} /$ forage sample. Four 75\% TMRT bags/heifer were also incubated on these 2 occasions for subsequent intestinal incubation (16 bags total). Time points included $0 \mathrm{~h}, 10 \mathrm{~h}, 75 \%$ TMRT, and $72 \mathrm{~h}$, and the bags were removed simultaneously. After incubation in the rumen, the 10-h, 75\% TMRT, and 72-h bags were washed in a washing machine for 15 min using 5 rinse cycles consisting of a 1min agitation and a 2 -min spin. Intestinal $75 \%$ TMRT bags were not washed but frozen $\left(-4^{\circ} \mathrm{C}\right)$ until insertion into the duodenum. All bags were subsequently refluxed in NDF solution to remove microbial contamination and to determine the NDIN pools (Mass et al., 1999). Four 0-h bags per sample were also refluxed in NDF solution and used to determine the potentially degradable (B) fraction by subtracting the 72-h NDIN (fraction C) from the 0-h NDIN.

In Exp. 2, 2 ruminally cannulated steers $(658 \mathrm{~kg})$ were offered a mixed diet of $65 \%$ alfalfa and $35 \%$ dry rolled corn twice daily, for a total intake of $2 \%$ of BW, and were used to incubate quadruplicate $10 \mathrm{~h}, 75 \%$ TMRT, and $72 \mathrm{~h}$ bags. Eight $75 \%$ TMRT bags were also incubated in the rumen in preparation for intestinal insertion.

\section{Mobile Nylon Bag Incubation}

Ruminally incubated bags (75\% TMRT) set aside for duodenal insertion were preincubated in a pepsin and $\mathrm{HCl}(1 \mathrm{~g}$ of pepsin/L and $0.01 \mathrm{~N} \mathrm{HCl} ; 62.5 \mathrm{~mL} / \mathrm{bag}$ ) solution at $37^{\circ} \mathrm{C}$ for $3 \mathrm{~h}$ to simulate abomasal digestion. In Exp. 1, 2 duodenally cannulated steers $(592 \mathrm{~kg})$ were used to incubate these bags over $8 \mathrm{~d}$. Steers were offered a mixed diet of $70 \%$ bromegrass hay and $30 \%$ concentrate twice daily, for a total intake of $1.5 \%$ of BW. Bags were inserted into the duodenum at $2 \mathrm{~h}$ after feeding at a rate of 1 bag every $0.1 \mathrm{~h}$, for a total of 8 bags (1 bag/forage) per steer daily. To correct for microbial contamination of the forage residues, bags were collected upon appearance in the feces and frozen until all bags were collected. Bags were machine-washed and bulk-refluxed in NDF solution. Bags were dried in a forced-air oven at $60^{\circ} \mathrm{C}$ for $48 \mathrm{~h}$, air equilibrated for 3 $\mathrm{h}$, and weighed. Residues were analyzed for $\mathrm{N}$ in a combustion analyzer (Leco FP-528, St. Joseph, MI) using the combustion method (AOAC, 1996).

In Exp. 2, 2 duodenally cannulated steers (658 kg) were used to incubate bags over $8 \mathrm{~d}$. Steers were fed a 
mixed diet of $65 \%$ alfalfa hay and $35 \%$ dry rolled corn twice daily, for a total intake of $2 \%$ of BW. Bags were inserted into the duodenum at $2 \mathrm{~h}$ postfeeding and collected in the feces beginning $12 \mathrm{~h}$ after insertion. A total of 12 bags ( 1 bag/forage) were incubated per steer daily at a rate of 1 bag every $0.1 \mathrm{~h}$. Bags collected in the feces were frozen until all bags were collected and then were machine-washed and bulk-refluxed in NDF solution before drying for $48 \mathrm{~h}$ at $60^{\circ} \mathrm{C}$. The bags were air-equilibrated for $3 \mathrm{~h}$, weighed, and $\mathrm{N}$ analysis was performed as previously described on the residue.

\section{Calculations}

Undegradable intake protein (\% DM) was calculated as: $(\mathrm{NDIN} \times 6.25) / \mathrm{sample} \mathrm{DM}$, in which NDIN was that remaining after incubation for 75\% TMRT. Undegradable intake protein (\% DM) was also calculated using a standard equation as described by Broderick (1994) and was modified to include a 10 -h passage lag (Klopfenstein et al., 2001, as follows: UIP $=\left\{\left[\left(1-\mathrm{k}_{\mathrm{d}}{ }^{10}\right) \times \mathrm{B}\right.\right.$ $\left.\times\left(\mathrm{k}_{\mathrm{p}} /\left(\mathrm{k}_{\mathrm{p}}+\mathrm{k}_{\mathrm{d}}\right)\right]+\mathrm{C}\right\} \times 6.25$, in which $\mathrm{k}_{\mathrm{d}}$ was the rate of ruminal degradation $(\% / \mathrm{h}), \mathrm{B}$ was the original $(0-\mathrm{h})$ NDIN minus the 72-h NDIN, and fraction $\mathrm{C}$ was the 72-h NDIN.

Neutral detergent insoluble $\mathrm{N}$ was measured on each in situ residue as well as on the original sample, allowing for the construction of a degradation curve for NDIN. The original (0-h) NDIN minus the 72-h NDIN represented the potentially degradable (B) fraction of NDIN. A first-order disappearance model was used to calculate the $\mathrm{k}_{\mathrm{d}}$ for each in situ CP fraction using the natural logarithm of the percentage of potentially degradable NDIN remaining (corrected for the 72-h undegradable fraction) against time. The following equation was used: $\mathrm{k}_{\mathrm{d}}(\% / \mathrm{h})=[\ln (\%$ of $\mathrm{B}$ remaining at $\mathrm{X})-\ln$ (\% of $\mathrm{B}$ remaining at $\mathrm{Y})]$ divided by $(\mathrm{X}-\mathrm{Y}, \mathrm{h})$, in which $\mathrm{X}$ and $\mathrm{Y}$ are any 2 time points.

In Exp. 1, the data were analyzed as a completely randomized design using the MIXED procedure of SAS (SAS Inst., Inc., Cary, NC) with treatments set up in a $2 \times 2$ factorial arrangement with forage and date as fixed effects. In Exp. 2, the treatments were arranged in a $2 \times 3$ factorial with $\mathrm{N}$ level and heat treatment as fixed effects in the model. Animal, day, and week were treated as random effects in both experiments. Least squares means were separated using the Least Significant Difference Method when a significant $(P<0.05)$ $F$-test was detected. Estimates of UIP calculated using the first order disappearance model were correlated to UIP estimates at a single time point (75\% TMRT) using the REG procedure of SAS.

\section{RESULTS AND DISCUSSION}

\section{Experiment 1}

In vitro DM disappearance, rate of passage TMRT, and 75\% TMRT for smooth bromegrass and birdsfoot
Table 1. In vitro dry matter disappearance, rate of passage, and incubation time points of smooth bromegrass and birdsfoot trefoil harvested in June and July

\begin{tabular}{lccccc}
\hline \hline & \multirow{2}{*}{ Item } & \multicolumn{2}{c}{ Smooth bromegrass } & & \multicolumn{2}{c}{ Birdsfoot trefoil } \\
\cline { 2 - 3 } \cline { 6 - 7 } & June & July & & June & July \\
\hline IVDMD, $\%$ & 59.9 & 52.9 & & 74.5 & 64.4 \\
$\mathrm{k}_{\mathrm{p}},{ }^{1} \% / \mathrm{h}$ & 3.99 & 3.50 & & 5.01 & 4.30 \\
$\mathrm{TMRT},{ }^{2} \mathrm{~h}$ & 35.0 & 38.6 & & 30.0 & 33.2 \\
$75 \% \mathrm{TMRT},{ }^{3} \mathrm{~h}$ & 26.3 & 28.9 & & 22.5 & 24.9 \\
\hline
\end{tabular}

${ }^{1}$ Rate of passage $\left(\mathrm{k}_{\mathrm{p}}, \% / \mathrm{h}\right)$ calculated as: $\mathrm{k}_{\mathrm{p}}=(0.07 \times \mathrm{IVDMD}, \%)$ -0.20 (Klopfenstein et al., 2001).

${ }^{2}$ Total mean retention time $($ TMRT, $h)=\left(1 / \mathrm{k}_{\mathrm{p}}\right)+10$.

${ }^{3}$ Incubation time point equivalent to $75 \%$ of the total mean retention time.

trefoil are shown in Table 1. Undegradable intake protein, indigestible dietary protein (IDP), digestibility of UIP, and intestinal disappearance of UIP (IDUIP) of smooth bromegrass and birdsfoot trefoil are shown in Table 2 . There was a forage $\times$ date interaction $(P<0.01)$ for the UIP, IDP, and digestibility of UIP. Undegradable intake protein of smooth bromegrass (\% DM) was similar $(P=0.11)$ in June and July; however, the UIP (\% DM) of birdsfoot trefoil increased from June to July $(P<0.01)$. Total tract indigestible dietary protein $(\%$ $\mathrm{DM})$ of smooth bromegrass increased from June to July $(P<0.01)$; however, the increase in IDP of birdsfoot trefoil was greater.

Although we did not measure tannin, there might have been sufficient tannin in birdsfoot trefoil in July to protect a larger fraction of the CP later in the summer because the IDUIP (\% DM) was 0.47 percentage units in July but only 0.28 percentage units in June $(P<$ 0.01 ). Tannins offer some protection from protein degradation in the rumen as a result of the tannin-protein complexes and inactivating enzymes. Tannins in legumes have been shown to decrease the CP degraded in the rumen (Barry et al., 1986); however, the tanninprotein complexes are not completely indigestible in the lower tract. The increase in IDP in July for smooth bromegrass resulted in a reduction in IDUIP (\% DM) from June to July $(P<0.01)$. The digestibility of the UIP of smooth bromegrass decreased in July from June due to the increase in IDP. Even though the increase in IDP was larger in birdsfoot trefoil in July, more UIP was flowing from the rumen, resulting in no difference $(P=0.07)$ in the digestibility (\%) of UIP of June and July.

Rate of protein degradation $\left(\mathrm{k}_{\mathrm{d}}, \% / \mathrm{h}\right)$ of smooth bromegrass and birdsfoot trefoil is shown in Table 3. There were 2-way interactions between sample and date, rate and date, and rate and sample $(P<0.01)$. The rate of protein degradation $\left(\mathrm{k}_{\mathrm{d}}, \% / \mathrm{h}\right)$ of smooth bromegrass was similar in June and July $(P=0.62)$. Protein degradation $\left(\mathrm{k}_{\mathrm{d}}, \% / \mathrm{h}\right)$ was more rapid in June than in July for birdsfoot trefoil $(P<0.01)$. In June, the rate from 0 to $10 \mathrm{~h}$ was more rapid $(P<0.01)$ than the rate from $10 \mathrm{~h}$ to $75 \%$ TMRT as well as the rates in 
Table 2. Protein characteristics of smooth bromegrass and birdsfoot trefoil harvested in June and July

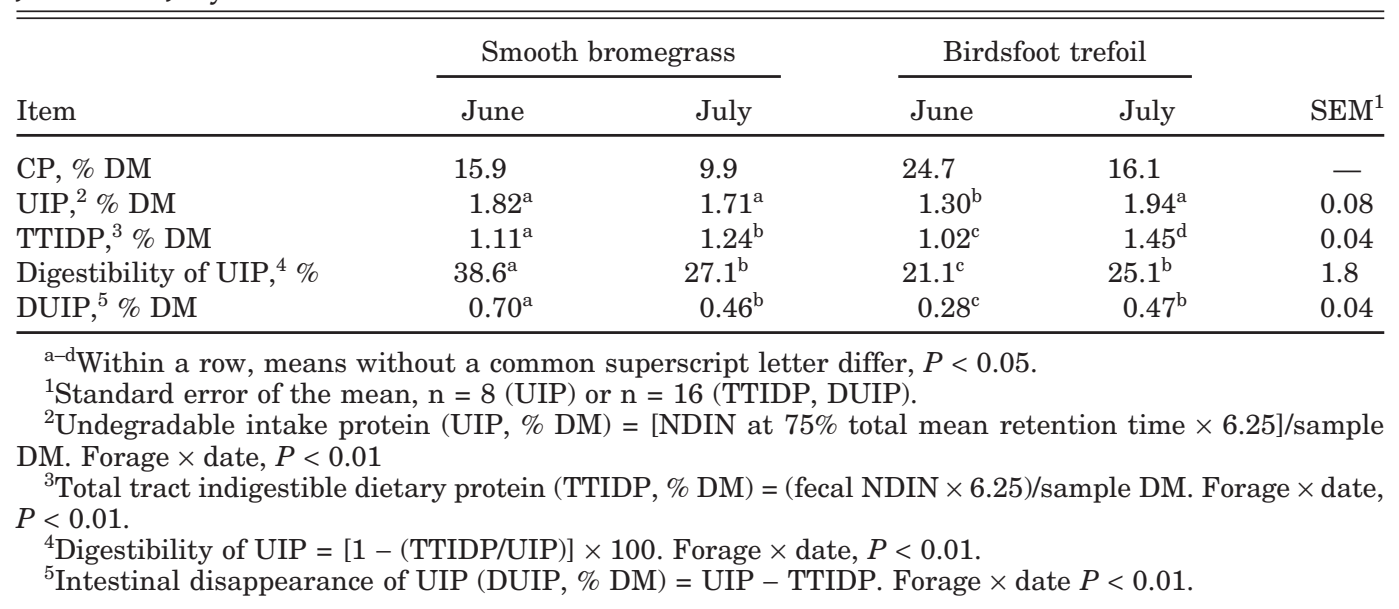

July from 0 to $10 \mathrm{~h}$ and $10 \mathrm{~h}$ to $75 \%$ TMRT. Averaged across harvest dates, the rate of degradation of birdsfoot trefoil was not different $(P=0.23)$ from 0 to $10 \mathrm{~h}$ and $10 \mathrm{~h}$ to $75 \%$ TMRT; however, the $\mathrm{k}_{\mathrm{d}}$ of smooth bromegrass from $10 \mathrm{~h}$ to $75 \%$ TMRT was slower $(P<0.01)$ than from 0 to $10 \mathrm{~h}$.

Undegradable intake protein (\% DM) values calculated using competing rates of passage and degradation are shown in Table 4. Equation UIP values were calculated using 2 rates of degradation from 0 to $10 \mathrm{~h}$ and $10 \mathrm{~h}$ to $75 \%$ TMRT as well as using a constant rate of degradation from 0 to $75 \%$ TMRT. Undegradable intake protein (\% DM) at 75\% TMRT were highly correlated $\left(\mathrm{R}^{2}=0.98\right)$ to the UIP values determined by the equation using a constant rate of degradation from 0 to $75 \%$ TMRT. Despite the differences observed in the rates of degradation from 0 to $10 \mathrm{~h}$ and $10 \mathrm{~h}$ to $75 \%$ TMRT, the use of 2 rates of degradation in the equation produced similar UIP values and had little effect on the regression of $75 \%$ TMRT values on the equation UIP values $\left(\mathrm{R}^{2}=0.96\right)$. These data are similar to those of Haugen et al. (2006).

\section{Experiment 2}

In vitro $\mathrm{DM}$ disappearance, rate of passage, and incubation time points of heat-treated alfalfa are shown in
Table 5. All alfalfa samples were incubated in situ for $23.5 \mathrm{~h}$ based on their estimated $75 \%$ TMRT. The addition of heat during the drying process increased the flow of UIP from the rumen $(P<0.01$; Table 6$)$. Nitrogen fertilization level had no effect on the UIP of alfalfa $(P=0.18)$. Indigestible protein $(\% \mathrm{DM})$ was not different for freeze-dried and sun-cured alfalfa (1.56); however, the IDP of dehydrated alfalfa was increased slightly above the other 2 drying methods $(P<0.01)$. There was a tendency $(P=0.06)$ for greater total tract IDP $(\% \mathrm{DM})$ in alfalfa fertilized with high amounts of $\mathrm{N}$ than at the low level of $\mathrm{N}$; however, this small increase in IDP did not adversely affect the digestibility of the UIP.

The application of heat to feeds is a potential way to decrease ruminal degradation of protein because heat generally reduces the solubility of cytoplasmic proteins (Van Soest, 1994). The binding of an aldehyde group of a sugar molecule to free AA groups creates an aminosugar complex (Ørskov, 1982). The heat-treatment of soybean meal is an example of a feedstuff that has been subject to the Maillard reaction to decrease ruminal protein degradation (Cleale et al., 1987). The heattreatment of alfalfa at oven temperatures $>60^{\circ} \mathrm{C}$ has been shown to reduce in vitro ammonia concentration compared with alfalfa dried at 40 or $60^{\circ} \mathrm{C}$, freeze-dried, or sun-cured (Krause and Klopfenstein, 1978). The use

Table 3. Rate of protein degradation $\left(\mathrm{k}_{\mathrm{d}}, \% / \mathrm{h}\right)$ for smooth bromegrass and birdsfoot trefoil harvested in June and July

\begin{tabular}{|c|c|c|c|c|c|}
\hline \multirow[b]{2}{*}{ Rate } & \multicolumn{2}{|c|}{ Smooth bromegrass } & \multicolumn{2}{|c|}{ Birdsfoot trefoil } & \multirow[b]{2}{*}{$\mathrm{SEM}^{1}$} \\
\hline & June & July & June & July & \\
\hline 0 to $10^{2}$ & $10.67^{\mathrm{a}}$ & $7.42^{\mathrm{b}}$ & $10.70^{\mathrm{a}}$ & $5.65^{\mathrm{b}}$ & 0.78 \\
\hline 10 to $75 \% \mathrm{TMRT}^{3}$ & $4.00^{\mathrm{a}}$ & $6.52^{\mathrm{b}}$ & $10.31^{\mathrm{c}}$ & $7.87^{\mathrm{b}}$ & 0.78 \\
\hline 0 to $75 \%$ TMRT $^{4}$ & $7.33^{\mathrm{a}}$ & $6.97^{\mathrm{a}}$ & $10.50^{\mathrm{b}}$ & $6.76^{\mathrm{a}}$ & 0.57 \\
\hline
\end{tabular}


Table 4. Undegradable intake protein (UIP; \% DM) values of smooth bromegrass and birdsfoot trefoil in June and July calculated using an equation and obtained at $75 \%$ total mean retention time

\begin{tabular}{lcccc}
\hline \hline & \multicolumn{4}{c}{ UIP, \% DM } \\
\cline { 2 - 5 } Forage & $\begin{array}{c}\text { Field } \\
\text { location }\end{array}$ & Equation $1^{1}$ & Equation $2^{2}$ & $\begin{array}{c}75 \% \\
\text { TMRT }^{3}\end{array}$ \\
\hline Smooth bromegrass & & & & \\
June & 1 & 1.94 & 1.78 & 1.88 \\
& 2 & 1.80 & 1.69 & 1.75 \\
July & 1 & 1.74 & 1.73 & 1.66 \\
& 2 & 1.86 & 1.83 & 1.77 \\
Birdsfoot trefoil & 1 & 1.20 & 1.22 & 1.17 \\
June & 2 & 1.43 & 1.41 & 1.42 \\
& 1 & 1.83 & 1.86 & 1.80 \\
July & 2 & 2.07 & 2.08 & 2.08 \\
& & & & \\
\hline
\end{tabular}

${ }^{1}$ Undegradable intake protein $=\left[\left\{\left(1-\mathrm{k}_{\mathrm{d}}{ }^{10}\right) \mathrm{B} \times\left(\mathrm{k}_{\mathrm{p}} /\left(\mathrm{k}_{\mathrm{p}}+\mathrm{k}_{\mathrm{d}}\right)\right)\right\}+\right.$ $\mathrm{C}] \times 6.25$, in which $\mathrm{k}_{\mathrm{d}}$ is the neutral detergent insoluble CP degradation from 0 to $75 \%$ TMRT; B is the initial pool of neutral detergent insoluble CP; $\mathrm{k}_{\mathrm{p}}$ is the rate of passage calculated from IVDMD; and $\mathrm{C}$ is the 72-h neutral detergent insoluble $\mathrm{CP}$.

${ }^{2}$ Undegradable intake protein $=\left[\left\{\left(1-\mathrm{k}_{\mathrm{dl}}{ }^{\wedge} 10\right) \mathrm{B} \times\left(\mathrm{k}_{\mathrm{p}} /\left(\mathrm{k}_{\mathrm{p}}+\mathrm{k}_{\mathrm{d} 2}\right)\right)\right\}+\right.$ $\mathrm{C}] \times 6.25$ where $\mathrm{k}_{\mathrm{d} 1}$ is the neutral detergent insoluble CP degradation from 0 to $10 \mathrm{~h} ; \mathrm{k}_{\mathrm{d} 2}$ is the neutral detergent insoluble CP degradation from $10 \mathrm{~h}$ to $75 \%$ TMRT; $\mathrm{B}$ is the initial pool of neutral detergent insoluble CP; $\mathrm{k}_{\mathrm{p}}$ is the rate of passage calculated from IVDMD; and $\mathrm{C}$ is the 72-h neutral detergent insoluble $\mathrm{CP}$.

${ }^{3}$ In situ incubation time point equivalent to $75 \%$ of the total mean retention time.

of heat to reduce the ruminally degradable protein in a highly degradable feed can be beneficial if the protected protein can subsequently be utilized by the animal.

The net effect of heat treatment on the digestibility of UIP was great as a result of the differences in UIP flowing to the small intestine (Table 6). The digestibility $(\%)$ of the UIP of dehydrated alfalfa was greater than sun-cured or freeze-dried $(P<0.01)$ alfalfa. The small increase in the IDP for dehydrated alfalfa was offset by the larger increase in the UIP flowing from the rumen and resulted in the greater digestibility of UIP. This response is in agreement with the work of Vanhatalo et al. (1995) in which a heat-moisture treatment was applied to rapeseed meals and used to study the effect on the intestinal $\mathrm{N}$ digestibility using the mobile nylon bag technique. The treatment of rapeseed with heat and moisture increased the UIP content by decreasing the rate of degradation and increasing the amount of the slowly degradable fraction without adversely affecting the intestinal $\mathrm{N}$ disappearance.

Disappearance of CP in the rumen, intestine, and total tract are shown in Table 7. Heat treatment influenced $(P<0.01)$ the disappearance of $\mathrm{CP}$ in the rumen and the small intestine. Crude protein disappearance (\%) in the rumen was the highest for freeze-dried alfalfa, followed by sun-cured and then dehydrated alfalfa. The levels of $\mathrm{N}$ fertilization responded differently to the 3 heat treatments; there was an interaction of $\mathrm{N}$ level and heat $(P=0.02)$ on the intestinal disappearance of CP. Levels of $\mathrm{N}$ did not affect $(P=0.40)$ the intestinal disappearance of $\mathrm{CP}(\%)$ in sun-cured or freeze-dried alfalfa; however, the intestinal disappearance of $\mathrm{CP}(\%)$ was greater $(P<0.01)$ at the high $\mathrm{N}$ level than at the low $\mathrm{N}$ level of fertilization for dehydrated alfalfa. Total tract disappearance of $\mathrm{CP}(\%)$ was reduced slightly for dehydrated alfalfa compared with sun-cured and freeze-dried alfalfa. Sun-cured and freeze-dried alfalfa did not differ in total tract CP disappearance $(P=0.10)$.

Hvelplund and Weisbjerg (2000) found total tract digestibility of alfalfa (27 samples) of $92.2 \%$ (SD 2.7). The disappearance of $\mathrm{CP}$ from the rumen, intestine, and total tract of alfalfa hay $(16.1 \% \mathrm{CP})$ measured by Erasmus et al. (1994) was 50.2, 32.7, and $82.9 \%$, respectively. The digestibility of the rumen undegradable protein in their study was $66.0 \%$; however, the $50.2 \% \mathrm{CP}$ disappearance from the rumen was much lower than that observed in the current study. A correction for microbial $\mathrm{N}$ was made, but ruminal incubations of 16 $\mathrm{h}$ used in the study of Erasmus et al. (1994) might not have accurately reflected the residence time of the forage particles in the rumen.

DeBoer et al. (1987) found that the rumen degradability of the CP in alfalfa after $24 \mathrm{~h}$ was $87.4 \%$, and intestinal disappearance was $8.4 \%$ for a total of $95.8 \% \mathrm{CP}$ disappearance in the total tract. The digestibility of

Table 5. In vitro DM disappearance, rate of passage, and incubation time points of heattreated $^{1}$ alfalfa from plots fertilized with low and high amounts ${ }^{2}$ of $\mathrm{N}$

\begin{tabular}{lccccccc}
\hline \hline & \multicolumn{2}{c}{ Dehydrated } & & \multicolumn{2}{c}{ Sun-cured } & & \multicolumn{2}{c}{ Freeze-dried } \\
\cline { 2 - 3 } \cline { 7 - 8 } Item & Low & High & & Low & High & Low & High \\
\hline IVDMD, $\%$ & 68.3 & 68.1 & & 71.2 & 69.7 & 72.0 & 70.8 \\
$\mathrm{k}_{\mathrm{p}}{ }^{3} \% / \mathrm{h}$ & 4.58 & 4.57 & & 4.79 & 4.68 & 4.84 & 4.76 \\
$\mathrm{TMRT}^{4}{ }^{\mathrm{h}} \mathrm{h}$ & 31.8 & 31.9 & & 30.9 & 31.4 & 30.7 & 31.0 \\
$75 \% \mathrm{TMRT},{ }^{5} \mathrm{~h}$ & 23.9 & 23.9 & & 23.2 & 23.5 & 23.0 & 23.3 \\
\hline
\end{tabular}

${ }^{1}$ Heat treatments applied: dehydrated, $100^{\circ} \mathrm{C}$ for $10 \mathrm{~h}$; sun-cured, $50^{\circ} \mathrm{C}$ for $15 \mathrm{~h}$; freeze-dried, $-50^{\circ} \mathrm{C}$ for $72 \mathrm{~h}$.

${ }^{2}$ Level of $\mathrm{N}$ fertilization: low $\left(66 \mathrm{~kg}\right.$ of $\left.\mathrm{N} \mathrm{ha}^{-1}\right)$ and high $\left(200 \mathrm{~kg}\right.$ of $\left.\mathrm{N} \mathrm{ha}^{-1}\right)$.

${ }^{3}$ Rate of passage $\left(\mathrm{k}_{\mathrm{p}}, \% / \mathrm{h}\right)$ calculated: $\mathrm{k}_{\mathrm{p}}=[0.07 \times \operatorname{IVDMD}(\%)]-0.20$ (Klopfenstein et al., 2001).

${ }^{4}$ Total mean retention time $($ TMRT $)=[1 \div(\mathrm{kp} \times 0.01)]+10$.

${ }^{5}$ Incubation time point equivalent to $75 \%$ of the total mean retention time. 
Table 6. Effect of heat treatment ${ }^{1}$ on the undegradable intake protein (UIP), total tract indigestible protein (TTIDP), and digestibility of UIP of alfalfa

\begin{tabular}{lcccc}
\hline \hline & Dehydrated & Sun-cured & Freeze-dried & \\
\cline { 2 - 4 } CP, \% DM & 20.5 & 21.1 & 20.9 & SEM $^{2}$ \\
\hline UIP, ${ }^{3} \%$ DM & $3.13^{\mathrm{a}}$ & $2.10^{\mathrm{b}}$ & $1.84^{\mathrm{c}}$ & 0.08 \\
$\mathrm{UIP},{ }^{4} \% \mathrm{CP}$ & $15.3^{\mathrm{a}}$ & $10.2^{\mathrm{b}}$ & $8.9^{\mathrm{c}}$ & 0.46 \\
TTIDP, ${ }^{\circ} \% \mathrm{DM}$ & $1.66^{\mathrm{a}}$ & $1.54^{\mathrm{b}}$ & $1.57^{\mathrm{b}}$ & 0.04 \\
TTIDP, ${ }^{\mathrm{b}} \% \mathrm{CP}$ & $8.06^{\mathrm{a}}$ & $7.37^{\mathrm{b}}$ & $7.60^{\mathrm{b}}$ & 0.16 \\
Digestibility of UIP, ${ }^{7} \%$ & $46.4^{\mathrm{a}}$ & $25.6^{\mathrm{b}}$ & $14.7^{\mathrm{c}}$ & 1.8 \\
\hline
\end{tabular}

${ }^{\mathrm{a}-\mathrm{c}}$ Within a row, means without a common superscript letter $\operatorname{differ}, P<0.05$.

${ }^{1}$ Heat treatments applied: dehydrated, $100^{\circ} \mathrm{C}$ for $10 \mathrm{~h}$; sun-cured, $50^{\circ} \mathrm{C}$ for $15 \mathrm{~h}$; freeze-dried, $-50^{\circ} \mathrm{C}$ for $72 \mathrm{~h}$

${ }^{2}$ Standard error of the mean; $\mathrm{n}=32$ (UIP) or $\mathrm{n}=64$ (TTIDP).

${ }^{3}$ Undegradable intake protein $(\mathrm{UIP}, \% \mathrm{DM})=(\mathrm{NDIN}$ at $75 \%$ total mean retention time*6.25)/sample DM.

Heat $\times$ sample, $P=0.21$.

${ }^{4}$ Undegradable intake protein $(\mathrm{UIP}, \% \mathrm{CP})=(\mathrm{NDIN}$ at $75 \%$ total mean retention time*6.25)/(sample DM $\times \% \mathrm{CP})$.

${ }^{5}$ Total tract indigestible protein $($ TTIDP,$\% \mathrm{DM})=($ fecal NDIN $\times 6.25) /$ sample DM. Heat $\times$ sample, $P=$ 0.59

${ }^{6}$ Total tract indigestible protein $($ TTIDP $\% \mathrm{CP})=($ fecal NDIN $\times 6.25) /($ sample $\mathrm{DM} \times \% \mathrm{CP})$.

${ }^{7}$ Digestibility of UIP $=[1-($ TTIDP/UIP $)] \times 100$. Heat $\times$ sample, $P=0.12$.

UIP for alfalfa was $66.7 \%$ in their experiment. Blank bags were included; however, microbial contamination was assumed to be nonexistent. Von Keyserlingk et al. (1996) tested 16 alfalfa hays and 14 grass hays and measured CP disappearance in the rumen and intestine. Alfalfa hays averaged $70.51 \% \mathrm{CP}$ disappearance from the rumen, and grass hays averaged $60.60 \% \mathrm{CP}$ disappearance from the rumen. Alfalfa hays averaged $18.07 \%$ disappearance in the intestine ranging from 10.74 to $36.64 \%$. Grass hay disappearance of $\mathrm{CP}$ in the intestine ranged from 9.20 to $48.68 \%$ and averaged $22.03 \%$. No correction for microbial $\mathrm{N}$ was made. The authors reported that the rumen incubations were 12 $h$ and may not have been long enough to represent the retention time of particles in the rumen.

Table 7. Disappearance of CP (\%) in heat-treated ${ }^{1}$ alfalfa from the rumen, intestine, and total tract

\begin{tabular}{lcccr}
\hline \hline Item & Dehydrated & Sun-cured & Freeze-dried & SEM $^{2}$ \\
\hline $\begin{array}{l}\text { Rumen, } \\
\text { Intestine } \% \text { CP }\end{array}$ \% CP & $84.8^{\mathrm{a}}$ & $89.8^{\mathrm{b}}$ & $91.2^{\mathrm{c}}$ & 0.45 \\
Low $^{5}$ & & & & \\
High $^{6}$ & $6.60^{\mathrm{a}}$ & $2.87^{\mathrm{b}}$ & $1.40^{\mathrm{c}}$ & 0.39 \\
Total tract, $^{7} \% \mathrm{CP}$ & $9.78^{\mathrm{a}}$ & $2.84^{\mathrm{b}}$ & $1.10^{\mathrm{c}}$ & 0.39 \\
\hline
\end{tabular}

${ }^{\mathrm{a}-\mathrm{c}}$ Within a row, means without a common superscript letter differ, $P<0.05$.

${ }^{1}$ Heat treatments applied: dehydrated, $100^{\circ} \mathrm{C}$ for $10 \mathrm{~h}$; sun-cured, $50^{\circ} \mathrm{C}$ for $15 \mathrm{~h}$; freeze-dried, $-50^{\circ} \mathrm{C}$ for $72 \mathrm{~h}$.

4).

Standard error of the mean; $n=32$ (rows 1 to 3 ) and $n=64$ (row

${ }^{3}$ Percent of total protein disappearing in the rumen (RDP, \%), calculated as [(initial $\mathrm{CP}-$ residue $\mathrm{CP}) /$ initial $\mathrm{CP}] \times 100$; heat, $P<0.01$; heat $\times$ sample, $P=0.20$.

${ }^{4}$ Percent of total protein disappearing in the intestine calculated as [(initial $\mathrm{CP}-\mathrm{RDP})-\mathrm{IDP}] \times 100$. Heat $\times \mathrm{N}$ level, $P=0.02$.

${ }^{5}$ Low $\mathrm{n}=66 \mathrm{~kg}$ of $\mathrm{N} / \mathrm{ha}$.

${ }^{6} \mathrm{High} \mathrm{n}=200 \mathrm{~kg}$ of $\mathrm{N} / \mathrm{ha}$.

${ }^{7}$ Total tract percent of total protein disappearance calculated as $\{1$ - $[\operatorname{IDP}(\% \mathrm{CP})]\} \times 100$. Heat, $P<0.01$; heat $\times$ sample, $P=0.23$.
Length of incubation of feeds in the rumen does not seem to largely affect the total tract digestibility of the feed (Beckers et al., 1996). In their experiment, total tract digestibilities of protein in meat and bone meal and soybean meal were similar across rumen incubation times ranging from 0 to $16 \mathrm{~h}$. Wheat bran total tract digestibility was lower at 0 and $2 \mathrm{~h}$ ruminal incubations but not different at 4-, 8-, 16-, or 24-h incubations. Length of incubation in the rumen does have a profound effect on site of protein disappearance because greater ruminal degradability is associated with lower intestinal digestibility within a feed (Beckers et al., 1996). This is important when determining digestibility of UIP. The heat-treated alfalfa used in the current study shows the effect of decreased ruminal degradability on lower intestinal tract digestibility values of the UIP fraction.

The rate of degradation $\left(\mathrm{k}_{\mathrm{d}}, \% / \mathrm{h}\right)$ of dehydrated alfalfa (5.60) was significantly slower than sun-cured (7.37) or freeze-dried (7.80) alfalfa. There was also a main effect of rate $(P<0.01)$ because the rate $(\% / \mathrm{h})$ from 0 to $10 \mathrm{~h}$ (8.09) was greater than from $10 \mathrm{~h}$ to $75 \%$ TMRT (5.75). In the study by Von Keyserlingk et al. (1996), the fractional rate of the B fraction of alfalfa was $6.61 \% / \mathrm{h}$. Neutral detergent insoluble $\mathrm{N}$ degradation of alfalfa was $13.8 \% / \mathrm{h}$ in a study by Coblentz et al. (1999). In this same study, ruminal escape of $\mathrm{N}$ in alfalfa at assumed passage rates of 2 and $6 \% / \mathrm{h}$ was 5.2 and $6.7 \% \mathrm{~N}$. In the current experiment, the ruminal escape of NDIN, based on the in situ incubation of $23.5 \mathrm{~h}$, was $2.4,1.6$, and $1.4 \% \mathrm{~N}$ for dehydrated, sun-cured, and freeze-dried alfalfa, respectively. These values were lower than those observed by Coblentz et al. (1999). The inclusion of the 10 -h passage lag in the current experiment reduces the protein escaping ruminal degradation and may explain some of the difference in the NDIN escape values reported.

Undegradable intake protein (\% DM) values calculated using the standard equation as well as at $75 \%$ 
the undegradable intake protein in the forages in the current study was low. Tabular values of the digestibility of undegradable intake protein in forages may overestimate the contribution of this fraction to the metabolizable protein in forage-fed animals. Incubation time of feeds in the rumen is a critical component in the determination of the digestibility of the undegradable intake protein of forages. Accurate quantification of the undegradable intake protein in forages requires separation of feed and microbial nitrogen, and determination of the undegradable intake protein in forages should include a correction for bacterial nitrogen. Protein insoluble in acid detergent solution might not be a good predictor of the indigestible dietary protein in some forages.

\section{LITERATURE CITED}

AOAC. 1996. Official Methods of Analysis. 16th ed. Assoc. Off. Anal. Chem., Arlington, VA.

Barry, T. N., T. R. Manley, and S. J. Duncan. 1986. The role of condensed tannins in the nutritional value of Lotus pedunculatus for sheep. Br. J. Nutr. 55:123-137.

Beckers, Y., A. Thewis, and B. Maudoux. 1996. Intestinal digestibility of rumen undegraded $\mathrm{N}$ of concentrates measured by the mobile nylon bag technique. Anim. Feed Sci. Technol. 61:305-323.

Broderick, G. A. 1994. Quantifying forage protein quality. Pages 200228 in Forage Quality, Evaluation, and Utilization. G. C. Fahey, Jr., ed. Am. Soc. Agronomy, Crop Sci. Soc. Am., Soil Sci. Soc. Am., Madison, WI.

Cleale, R. M., R. A. Britton, T. J. Klopfenstein, M. L. Bauer, D. L. Harmon, and L. D. Satterlee. 1987. Induced non-enzymatic browning of soybean meal. II. Ruminal escape and net portal absorption of soybean protein treated with xylose. J. Anim. Sci. 65:1319-1326.

Coblentz, W. K., J. O. Fritz, W. H. Fick, R. C. Cochran, J. E. Shirley, and J. E. Turner. 1999. In situ disappearance of neutral detergent insoluble nitrogen from alfalfa and eastern gamagrass at three maturities. J. Anim. Sci. 77:2803-2809.

DeBoer, G., J. J. Murphy, and J. J. Kennedy. 1987. Mobile nylon bag for estimating intestinal availability of rumen undegradable protein. J. Dairy Sci. 70:977-982.

Erasmus, L. J., P. M. Botha, and C. W. Cruywagen. 1994. Amino acid profile and intestinal digestibility of dairy cows of rumenundegradable protein from various feedstuffs. J. Dairy Sci. 77:541-551.

Frydrynch, Z. 1992. Intestinal digestibility of rumen undegraded protein of various feeds as estimated by the mobile bag technique. Anim. Feed Sci. Technol. 37:161-172.

Haugen, H. L., M. J. Lamothe, T. J. Klopfenstein, D. C. Adams, and M. D. Ullerich. 2005. Estimation of undegradable intake protein in forages using neutral detergent insoluble nitrogen at a single in situ incubation time point. J. Anim. Sci. 84:651-659.

Hvelplund, T., and M. R. Weisbjerg. 2000. In situ techniques for the estimation of protein degradability and postrumen availability. Pages 233-258 in Forage Evaluation in Ruminant Nutrition. D.
I. Given, E. Owen, R.F.E. Axford, and H. M. Omed, ed. CABI Publ., New York, NY.

Klopfenstein, T., and R. Britton. 1987. Heat damage-real or artifact. Pages 84-86 in Proceedings of Distillers Feed Conference. Distillers Feed Res. Counc., Cincinnati, $\mathrm{OH}$.

Klopfenstein, T. J., R. A. Mass, K. W. Creighton, and H. H. Patterson. 2001. Estimating forage protein degradation in the rumen. J. Anim. Sci. 79(Suppl. 1):208-217.

Krause, V., and T. Klopfenstein. 1978. In vitro studies of dried alfalfa and complementary effects of dehydrated alfalfa and urea in ruminant rations. J. Anim. Sci. 46:499-504.

Mass, R. A., G. P. Lardy, R. J. Grant, and T. J. Klopfenstein. 1999. In situ neutral detergent insoluble nitrogen as a method for measuring forage protein degradability. J. Anim. Sci. 77:1565-1571.

NRC. 1996. Nutrient Requirements of Beef Cattle. Natl. Acad. Press, Washington, DC.

NRC. 2001. Nutrient Requirements of Dairy Cattle. Natl. Acad. Press, Washington, DC.

Negi, S. S., B. Singh, and H. P. S. Makkar. 1988. An approach to the determination of rumen degradability of nitrogen in low-grade roughages and partition of nitrogen therein. J. Agric. Sci. Camb. 111:487-493.

Ørskov, E. R. 1982. Protein Nutrition in Ruminants. Pages 40-84. Acad. Press, New York, NY.

Sniffen, C. J., J. D. O'Connor, P. J. Van Soest, D. J. Fox, and J. B. Russell. 1992. A net carbohydrate and protein system for evaluating cattle diets. II. Carbohydrate and protein availability. J. Anim. Sci. 70:3562-3577.

Tilley, J. M. A., and R. A. Terry. 1963. A two-stage technique for the in vitro digestion of forage crops. J. Brit. Grassl. Soc. 18:104-111.

Vanhatalo, A., I. Aronen, and T. Varvikko. 1995. Intestinal nitrogen digestibility of heat-moisture treated rapeseed meals as assessed by the mobile-bag method in cows. Anim. Feed Sci. Technol. 55:139-152.

Van Soest, P. J. 1994. Pages 292-296 in Nutritional Ecology of the Ruminant. 2nd ed. Cornell Univ. Press, Ithaca, NY.

Van Soest, P. J., and V. C. Mason. 1991. The influence of the Maillard reaction upon the nutritive value of fibrous feeds. Anim. Feed Sci. Technol. 32:45-53.

Van Soest, P. J., C. J. Sniffen, D. R. Mertens, D. G. Fox, P. H. Robinson, and U. C. Krishnamoorthy. 1982. A net protein system for cattle: The rumen submodel for nitrogen. Page 265 in Protein Requirements for Cattle: Proceedings of an International Symposium MP-109. F. N. Owens, ed. Div. Agric., Oklahoma State Univ., Stillwater.

Vanzant, E. S., R. C. Cochran, and E. C. Titgemeyer. 1998. Standardization of in situ techniques for ruminant feedstuff evaluation. J. Anim. Sci. 76:2717-2729.

Voigt, J., B. Piatkowski, H. Engelmann, and E. Rudolph. 1985. Measurement of the postruminal digestibility of crude protein by the bag technique in cows. Arch. Tierernaahr. Berlin 35:555-562.

Von Keyserlingk, M. A. G., M. L. Swift, R. Puchala, and J. A. Shelford. 1996. Degradability characteristics of dry matter and crude protein of forages in ruminants. Anim. Feed Sci. Technol. 57:291-311.

Weiss, W. P. 1994. Estimation of digestibility of forages by laboratory methods. Pages 644-681 in Forage Quality, Evaluation, and Utilization. G. C. Fahey, Jr., ed. Am. Soc. Agronomy, Crop Sci. Soc. Am., and Soil Sci. Soc. Am., Madison, WI. 